\title{
Gender Effect on Some Blood Parameters in Patients Undergoing Haemodialysis in North Western Algeria
}

\author{
Mouna MEGHRAOUI ${ }^{1}$, Achouak Kheira MEDDAH ${ }^{1}$, Mustapha DIAF $^{1}$, Mohamed DIAF $^{2}$ \\ ${ }^{1}$ Department of Biology, Faculty of Natural and Life Sciences, Djillali LIABES University of Sidi-Bel-Abbes \\ ${ }^{2}$ Nephrology and dialysis department, "BOURAS Miloud" Hospital of Tabia, Sidi-Bel-Abbès, Algeria
}

\section{* Corresponding Author email: diafmustapha@gmail.com}

Article Histary

Received: 30 March 2020

Revised: 02 June 2020

Accepted: 20 June 2020

Published: 03 July 2020

\section{Student(s)}

- Mouna MEGHRAOUI

- Achouak Kheira MEDDAH

Academic Year: 2019-2020

Course Level: Master

Course Name: M.Sc. (Cellular Biology)

Course year: $2^{\text {nd }}$ Year

Mentar(s)

- Mustapha DIAF

- Mohamed DIAF

\section{ABSTRACT}

Replacement therapy for chronic kidney disease using haemodialysis involves the elimination of excessive toxic fluids and toxic metabolic end products from the body. Worldwide, gender significant differences exist with regard to the epidemiological aspect, evolution and blood parameters of chronic renal failure disease. In the present retrospective study, 289 medical files of adult patients (154 men and 135 women) aged 20 to 78 years were investigated to understand the relationship between gender difference and blood parameters in patients with chronic renal failure undergoing haemodialysis in north western Algeria. Our results revealed significant higher levels of haemoglobin $(p=0.003)$, haematocrit $(p=0.005)$, creatinine $(p<0.001)$ and uric acid $(p=0.037)$ in men comparing to women. However, women serum samples were characterized by higher significant level of platelets $(p=0.002)$. No significant differences $(p>0.005)$ were observed between the two genders regarding the other parameters of blood count formula, liver function parameters, urea, mineral status (calcemia and phosphoremia), basic biochemical levels (glycaemia and lipids), C-reactive protein (CRP) and parathyroid hormone (PTH). In dialysis patients, and despite the fact that some serum parameters vary significantly, the majority of the parameters recorded were often high in the males compared to the female gender. This finding may be due to the existence of specific confounding prognostic factors for each sex, which may or may not compensate for each other, therefore, ultimately, leading to overall non-significance.

Keywords: haemodialysis, blood parameters, gender difference, north western Algeria. 


\section{Introduction}

Currently, nearly 2.6 million patients worldwide have different kidney diseases [1], the major problem in these patients remains the risk of developing different complications such as heart disease, high blood pressure, anaemia and inflammation [2]. However, when kidney failure becomes chronic, through gradual progression - over a period of weeks, months or years - the kidneys slowly stop functioning, there is a terminal kidney disease [3]. An adequate treatment protocol must take into account gender differences, since not only demographic characteristics, but also many clinical, laboratory and therapeutic parameters can affect morbidity and mortality and differ considerably between the two genders [4].

Haemodialysis is one of the kidney replacement treatments [5]. The technique plays an essential role in the process of extracorporeal elimination of waste when the kidneys are affected. The haemodialysis procedure is performed two to three times a week over two to four hours. The duration of dialysis varies according to many factors, including kidney function, the waste amount in the body, the level of salts and body weight [6]. Our present study was performed in order to understand the relationship between gender difference and blood parameters in patients with chronic renal failure undergoing haemodialysis in north western Algeria.

\section{Materials and Methods}

\subsection{Patients and study localization}

This retrospective study involved two hundred and eighty-nine blood samples, of patients with chronic renal failure undergoing haemodialysis, collected from Tabia Hospital "BOURAS Miloud", in Sidi-BelAbbès, north-western Algeria. Ethical approval for performing the present study was taken from the scientific council of the faculty of natural and life sciences, Djillali LIABES University. The patient's medical records were checked respecting the rules of anonymity with protecting the personal information of each patient.

\subsection{Studied parameters}

Results of blood samples analysis were taken from patients' medical record. The following blood parameters were considered: blood count formula, liver function parameters (ASAT and ALAT), renal parameters (urea, creatinine and uric acid), mineral status (calcemia and phosphoremia), basic biochemical levels (glycaemia and lipids), C-reactive protein (CRP) and parathyroid hormone (PTH).

\subsection{Statistical Analysis}

The Statistical Package for Social Sciences (SPSS, version 24.0) program was used in this study. All values were expressed as Mean \pm Standard Deviation (SD). The Student ' $\mathrm{t}$ ' test for independent variables was considered significant when the probability $(p)$ was less than 0.05 ( $p>0.05)$.

\section{Results and Discussion}

The study population consisted of 154 men and 135 women, their mean age was 52.52 \pm 12.31 years ( $48.51 \pm 9.88$ years, in men $v$ s. $57.09 \pm 13.22$ years, in women) and ranged from 20 to 78 years. Our results show a significant higher level $(p<0.05)$ of haemoglobin, haematocrit and platelets in men comparing to women (table 1). However, higher non-significant levels of red blood cells, mean cell volume (MCV), leucocytes and mean corpuscular haemoglobin concentration (MCHC) were observed in women. Several studies have shown that there are differences between males and females in hematological parameters like sodium, potassium, calcium, creatinine, amylase, total protein, albumin, phosphate and lever enzymes. The levels of these parameters are usually higher in males. Parameters like platelets, eosinophils, basophils, red cell counts, hemoglobin and hematocrit tend to vary among sex and age group [7, 8].

Our results indicate that the vast majority of our patients have anaemia. Similar results were reported by Anees et al., 2018 who found that $91.2 \%$ of kidney failure patients had anaemia [9]. Indeed, the endogenous 
erythropoietin deficiency, the uremic inhibitors and the shortened red blood cells survival are the main cause of anaemia in haemodialysis patients [10]. However, anaemia aggravates exercise tolerance, cognitive competence and reduces quality of life in dialysis patients [11]. Several authors stated that the haemoglobin is one of the most affected haematological parameters in patients with kidney failure $[2,12,13]$.

Table 1. Comparison of the complete blood count results between men and women

\begin{tabular}{|c|c|c|c|c|}
\hline & All patients & Males & Females & $p$ value* \\
\hline Red Blood Cells (millions $/ \mathrm{mm}^{3}$ ) & $3.69 \pm 0.17$ & $\begin{array}{l}3.62 \pm 0.74 \\
{[4.2-5.7]}\end{array}$ & $\begin{array}{l}3.78 \pm 0.25 \\
{[4.0-5.3]}\end{array}$ & 0.518 \\
\hline Haemoglobin $(\mathrm{g} / 100 \mathrm{ml})$ & $10.66 \pm 1.97$ & $\begin{array}{l}10.99 \pm 1.81 \\
{[14.0-17.0]}\end{array}$ & $\begin{array}{l}10.28 \pm 2.08 \\
{[12.5-15.5]}\end{array}$ & 0.003 \\
\hline Haematocrit (\%) & $37.77 \pm 7.28$ & $\begin{array}{l}33.22 \pm 7.14 \\
{[40-52]}\end{array}$ & $\begin{array}{l}29.84 \pm 7.07 \\
{[37-46]}\end{array}$ & 0.005 \\
\hline Mean Cell Volume (MCV) $\left(\mu^{3}\right)$ & $88.76 \pm 11.98$ & $\begin{array}{l}88.14 \pm 12.93 \\
{[80-95]}\end{array}$ & $\begin{array}{l}89.55 \pm 10.79 \\
{[80-95]}\end{array}$ & 0.603 \\
\hline Leukocytes $\left(/ \mathrm{mm}^{3} \mathrm{x} 1000\right)$ & $6.66 \pm 0.24$ & $\begin{array}{l}6.46 \pm 0.23 \\
{[4.0-10.0]}\end{array}$ & $\begin{array}{l}6.91 \pm 0.25 \\
{[4.0-10.0]}\end{array}$ & 0.203 \\
\hline $\begin{array}{lcl}\text { Mean } & \text { Corpuscular } & \text { Haemoglobin } \\
\text { Concentration }(\mathrm{MCHC})(\%) & \end{array}$ & $26.11 \pm 1.22$ & $\begin{array}{l}25.66 \pm 1.32 \\
{[30-35]}\end{array}$ & $\begin{array}{l}27.08 \pm 1.04 \\
{[30-35]}\end{array}$ & 0.779 \\
\hline Platelets $\left(/ \mathrm{mm}^{3} \mathrm{x} 1000\right)$ & $214.43 \pm 71.87$ & $\begin{array}{l}200.65 \pm 75.70 \\
{[150-400]}\end{array}$ & $\begin{array}{l}229.82 \pm 64.25 \\
{[150-400]}\end{array}$ & 0.002 \\
\hline
\end{tabular}

(*) $p$ value of student $t$ test, a $p<0.05$ was considered as significant. In square brackets, the target values.

According to Pandian et al. (2017), anaemia due to a reduction in haemoglobin levels is a common complication encountered in dialysis patients [14]. The same conclusions have been done by Suega et al. (2005) [15] and Bhatta et al. (2011) [16].

Table 2 displayed a comparison of liver enzymes serum levels (Aspartate Transaminase "ASAT" and Alanine Aminotransferase "ALAT") between men and women. Normal low rates have been recorded for both enzymes in our patients, although, these rates are high in women comparing to men. Several recent studies have revealed that serum ALT levels are lower in dialysis patients [17-19]. All the same, in their study done in Italy, Fabrizi et al. (2001) found lower ASAT and ALAT levels among dialysis patients compared to predialysis ones [20]. According to van Beek et al. (2013), in haemodialysis patients, the observed variations between males and females in ASAT and ALAT serum may be partly due to hereditary factors and are impacted by the biological effects of chronic renal failure disease and the patient environment. The latter would comprise metabolic risk issues such as dyslipidaemia, inflammation, alcohol use, smoking, vitamin D levels and coffee consumption [21].

Table 2. Effect of sex differences on the liver transaminases

\begin{tabular}{|l|l|l|l|l|}
\hline & All patients & Males & Females & $\boldsymbol{p}$ value* \\
\hline Alanine Aminotransferase (ALAT) (IU/L) & $14.34 \pm 1.04$ & $13.71 \pm 0.99$ & $14.98 \pm 1.09$ & 0.565 \\
& & {$[8-45]$} & {$[6-35]$} & \\
\hline Aspartate Transaminase (ASAT) (IU/L) & $19.37 \pm 1.01$ & $17.92 \pm 0.86$ & $20.94 \pm 1.14$ & 0.142 \\
& & {$[10-40]$} & {$[10-35]$} & \\
\hline
\end{tabular}

(*) $\mathrm{p}$ value of student $\mathrm{t}$ test, a $\mathrm{p}<0.05$ was considered as significant. In square brackets, the target values.

In numerous studies, a strong association was observed between serum creatinine and serum urea levels among renal failure patients undergoing or not haemodialysis. However, both serum creatinine and serum urea are accepted putative indices to evaluate the renal functions. Our results, summarized in table 3 , indicate a higher significant level of urea, creatinine $(p<0.001)$ and uric acid $(p=0.037)$ in male dialysis patients comparing to females. These results are consistent with those of Ul Amin et al. (2014) where creatinine and urea levels were commonly higher in male dialysis patients than women [22]. Several Scientifics affirmed 
that, every day, $2 \%$ of creatine is converted into creatinine, that's why the normal values for creatinine are in the range of (male: 20 to $25 \mathrm{mg} / \mathrm{kg} /$ day; female 15 to $20 \mathrm{mg} / \mathrm{kg} / \mathrm{day}$ ) [2]. This difference between males and females is explained by the greater muscle mass in men comparing to women.

Table 3. Comparison of renal function tests between the two genders

\begin{tabular}{|l|c|c|c|l|}
\hline & All patients & Males & Females & $\boldsymbol{p}$ value* \\
\hline Urea $(\mathrm{g} / \mathrm{L})$ & $1.57 \pm 0.50$ & $1.65 \pm 0.53$ & $1.47 \pm 0.45$ & 0.772 \\
& & {$[0.1-0.55]$} & {$[0.1-0.55]$} & \\
\hline Creatinine $(\mathrm{mg} / \mathrm{L})$ & $81.30 \pm 2.85$ & $89.97 \pm 3.03$ & $71.75 \pm 2.30$ & $<0.001$ \\
& & {$[5-15]$} & {$[5-15]$} & \\
\hline Uric acid $(\mathrm{mg} / \mathrm{L})$ & $47.19 \pm 2.17$ & $50.04 \pm 2.30$ & $43.66 \pm 1.95$ & 0.037 \\
& & {$[40-60]$} & {$[40-60]$} & \\
\hline
\end{tabular}

(*) $p$ value of student $t$ test, a $p<0.05$ was considered as significant. In square brackets, the target values.

As shown in table 4, we compared serum calcium and phosphorus between males and females undergoing dialysis. Our results displayed normal higher non-significant levels of both serum calcium $(p=0.430)$ and phosphorus $(p=0.519)$ in males comparing to females. There is controversy over the association of gender with the mineral parameters in patients with chronic kidney disease. In contrast to our study, Artan et al. (2016) reported that control of serum phosphorus was better in women compared to men [4]. The main reasons are probably the efficiency of dialysis, which results in greater phosphorus clearance, compliance with a strict diet and/or better adhesion to phosphate binders [4]. According to the JSDT clinical practice guidelines, the management of serum phosphorus is of greater priority [23]. Collinson et al. (2014) reported that the gender difference may be a factor influencing the control of chronic kidney disease-related minerals [24].

Table 4. Gender effect on mineral status

\begin{tabular}{|l|l|l|l|l|}
\hline & All patients & Males & Females & $\boldsymbol{p}$ value* \\
\hline Calcemia $(\mathrm{mg} / \mathrm{L})$ & $99.75 \pm 3.29$ & $102.57 \pm 2.68$ & $96.62 \pm 3.88$ & 0.430 \\
& & {$[85-105]$} & {$[85-105]$} & \\
\hline Phosphoremia $(\mathrm{mg} / \mathrm{L})$ & $37.39 \pm 2.32$ & $38.36 \pm 2.46$ & $36.15 \pm 2.12$ & 0.519 \\
& & {$[30-40]$} & {$[30-40]$} & \\
\hline
\end{tabular}

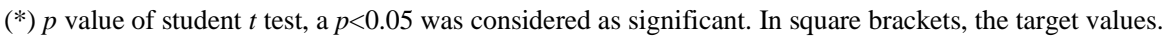

Our outcomes about glycaemia, total cholesterol and triglycerides indicates normal range of these parameters in our population (table 5), except the higher level of triglycerides in females. However, the comparison between males and females revealed non-significant differences $(p>0.005)$. Similar results have been reported by Rusul Arif et al. (2000) [3]. All, the same no significant effect of gender was observed on C-reactive protein (CRP) and parathyroid hormone (PTH) levels in our study population (table 6). Though, the levels of these two parameters in men were higher than those observed in women in accordance with previous reports [25]. The explanation for this result is ambiguous; probably, poorer control of phosphorus serum level and less regular vitamin D usage may explain this conclusion.

Table 5. Comparison of basic biochemical parameters between males and females

\begin{tabular}{|l|l|l|l|l|}
\hline & All patients & Males & Females & $\boldsymbol{p}$ value* \\
\hline Fasting glycaemia (g/L) & $1.02 \pm 0.51$ & $0.99 \pm 0.48$ & $1.06 \pm 0.54$ & 0.321 \\
& & {$[0.8-1.0]$} & {$[0.8-1.0]$} & \\
\hline Total cholesterol (g/L) & $2.39 \pm 1.21$ & $1.42 \pm 0.38$ & $3.79 \pm 1.89$ & 0.179 \\
& & {$[1.15-2.7]$} & {$[1.15-2.7]$} & \\
\hline Triglycerides (g/L) & $1.31 \pm 0.80$ & $1.36 \pm 0.12$ & $1.24 \pm 0.84$ & 0.453 \\
& & {$[0.6-1.7]$} & {$[0.6-1.7]$} & \\
\hline
\end{tabular}

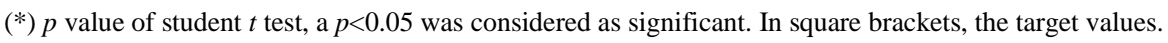


Meghraoui et al., Adv.J. Grad. Res.; Vol. 8, Issue 1, pp: 115-120, July 2020

Table 6. Comparison of C-reactive protein and Parathyroid hormone levels between men and women

\begin{tabular}{|l|l|l|l|l|}
\hline & All patients & Males & Females & $\boldsymbol{p}$ value* \\
\hline C-reactive protein $(\mathrm{CRP})(\mathrm{mg} / \mathrm{L})$ & $339.25 \pm 19.05$ & $\begin{array}{l}422.66 \pm 20.41 \\
{[<10]}\end{array}$ & $\begin{array}{l}267.76 \pm 17.32 \\
{[<10]}\end{array}$ & 0.166 \\
\hline Parathyroid hormone $(\mathrm{PTH})(\mathrm{pg} / \mathrm{L})$ & $463.55 \pm 48.77$ & $499.19 \pm 57.24$ & $392.26 \pm 26.58$ & 0.623 \\
& & {$[132.0-640.0]$} & {$[132.0-640.0]$} & \\
\hline
\end{tabular}

(*) $p$ value of student $t$ test, a $p<0.05$ was considered as significant. In square brackets, the target values.

\section{Conclusion}

In dialysis patients, and under the light of above results, serum parameters vary significantly and the majority were often higher in males compared to the female gender. A firm relationship was observed between male gender and higher levels of hemoglobin, hematocrits, renal function tests, mineral status and parathyroid hormone. It is imperative to raise the feasibility of using single target for all patients undergoing hemodialysis under different conditions.

\section{Declarations}

\subsection{Acknowledgements}

The authors express their heartfelt thanks to all the staff of the Nephrology and dialysis department, "BOURAS Miloud" Hospital of Tabia, Sidi-Bel-Abbès, Algeria.

\subsection{Ethical Approval}

Ethical approval for performing the present study was taken from the scientific council of the faculty of natural and life sciences, Djillali LIABES University. The patient's medical records were checked respecting the rules of anonymity with protecting the personal information of each patient.

\subsection{Competing Interests}

No conflict of interest exists in this publication.

\section{How to Cite This Article:}

M. MEGHRAOUI, A. K. MEDDAH, M. DIAF, and M. DIAF, "Gender Effect on Some Blood Parameters in Patients Undergoing Haemodialysis in North Western Algeria”, Adv. J. Grad. Res., vol. 8, no. 1, pp. 115-120, Jul. 2020. https://doi.org/10.21467/ajgr.8.1.115-120

\section{References}

[1] M. Miura, A. Hirayama, S. Oowada, A. Nishida, C. Saito, K. Yamagata, O. Ito, Y. Hirayama, M. Kohzuki, "Effects of electrical stimulation on muscle power and biochemical markers during hemodialysis in elderly patients: a pilot randomized clinical trial", Renal Replacement Therapy, vol. 4, no. 33, pp. 1-8, Sep. 2018. https://doi.org/10.1186/s41100-018-0174-7

[2] R. Nisha, S. R. S. Kannan, K. T. Mariappan, P. Jagatha, "Biochemical evaluation of creatinine and urea in patients with renal failure undergoing hemodialysis”, J. Clin. Path. Lab. Med., vol. 1, no. 2, pp. 1-5, Jul. 2017.

[3] A. Rusul Arif, S. Haider, "A study of some biochemical changes in patients with chronic renal failure undergoing hemodialysis", Int. J. Curr. Microbiol. App. Sci., vol. 3, no. 5, pp. 581-586, 2014.

[4] S. Artan, F. Kircelli, E. Ok, M. Yilmaz, G. Asci, C. Dogan, O. Oto, K. Gunestepe, A. Basci, M. S. Sever, "Dialyzing women and men: does it matter? An observational study", Clinical Kidney Journal, vol. 9, no. 3, pp. 486-493, Jun. 2016. doi: 10.1093/ckj/sfw013

[5] S. Raghunandan, S. Deepak Kumar, M. Ram Lakhan, "Effectiveness of Self Instructional Module (SIM) on knowledge regarding home care management among patients with chronic renal failure undergoing haemodialysis at selected hospital of Punjab", IOSR J. Nurs. Health Sci., vol. 5, no. 6, pp. 20-31, 2016.

[6] W.P. Samaneka, G. Mandozana, W. Tinago, N. Nhando, N.M. Mgodi, M.F. Bwakura-Dangarembizi, M.W. Munjoma, Z.A.R. Gomo, Z.M. Chirenje, J.G. Hakim, "Adult Hematology and Clinical Chemistry Laboratory Reference Ranges in a Zimbabwean Population”, PLoS One, vol. 11, no. 11, e0165821, 2016. https://doi:10.1371/journal.pone.0165821

[7] P. Gomani, A.T. Matubu, H.A. Mujuru, M.W. Munjoma, W. Tinago, G. Mandozana, J.G. Hakim, Z.A.R. Gomo, Z.M. Chirenje, "Hematological and Biochemical Laboratory Reference Intervals for Zimbabwean Adolescents", Clin Lab, vol. 61, no. 1-2, pp. 101111, 2015. https://doi:10.7754/clin.lab.2014.140506M. 
[8] Unruh, M. Kurella Tamura, B. Larive, A. Rastogi, S. James, B. Schiller, J. Gassman, C. Chan, R. Lockridge, A. Kliger, "Impact of sleep quality on cardiovascular outcomes in hemodialysis patients: results from the frequent hemodialysis network study", Am. $J$. Nephrol., vol. 33, no. 5, pp. 398-406, 2011. doi: 10.1159/00032634.

[9] M. Anees, Y. Hussain, M. Ibrahim, I. Ilahi, S. Ahmad, K.I. Asif, A. Jameel, "Outcome of Chronic Kidney Disease Patients on the Basis of Referral to Nephrologist: A One-Year Follow-up Study”, J Coll Physicians Surg Pak, vol. 28, no. 4, pp.304-307, 2018. doi:10.29271/jcpsp.2018.04.304.

[10] R.J. McGonigle, J.D. Wallin, R.K. Shadduck, J.W. Fisher, "Erythropoietin deficiency and inhibition of erythropoiesis in renal insufficiency”, Kidney Int, vol. 25, no. 2, pp. 437-444, 1984. doi:10.1038/ki.1984.36.

[11] C.P. Kovesdy, B.K. Trivedi, K. Kalantar-Zadeh, J.E. Anderson, "Association of anemia with outcomes in men with moderate and severe chronic kidney disease”, Kidney Int, vol. 69, no. 3, pp. 560-564, 2006. doi:10.1038/sj.ki.5000105.

[12] A. Muhammad, M. Zeb, M. Khan, H. Hayat, M. Hameed, A. Ullah, “Anemia in End Stage Renal Failure Patients", Annals of Allied Health Sciences, vol. 4, no. 2, pp. 52-55, 2019.

[13] N. Asif, S. Hasan, K. Hassan, "Hematological Changes in Patients of Chronic Renal Disease and Their Response to Treatment with Erythropoietin", Int. j. pathol., vol. 13, no. 1, pp. 14-19, 2015.

[14] J. Pandian, K. Amitkumar, A. Swaminathan, "Assessment of impact of hemodialysis on hematological parameters among patients with chronic kidney disease”, Comp. Clin. Pathol., vol. 26, pp. 213-218, Nov. 2017. https://doi.org/10.1007/s00580-016-2372-4.

[15] K. Suega, M. Bakta, T. G. Dharmayudha, J. S. Lukman, K. Suwitra, "Profile of anemia in chronic renal failure patients: comparison between predialyzed and dialyzed patients at the Division of Nephrology, Department of Internal Medicine, Sanglah Hospital, Denpasar, Bali, Indonesia”, Acta Med. Indones., vol. 37, no. 4, pp. 190-194, Dec. 2005.

[16] S. Bhatta, G Aryal, RK Kafle, "Anemia in chronic kidney disease patients in predialysis and postdialysis stages", Journal of Pathology of Nepal, vol. 1, no. 1, pp. 26-29, 2011. https://doi.org/10.3126/jpn.v1i1.4446

[17] E. P. Lopes, L. H. Sette, J. B. Sette, C. F. Luna, A. M. Andrade, M. Moraes, P. C. Sette, R. Menezes, R. L. Cavalcanti, S. C. Conceição, "Serum alanine aminotransferase levels, hematocrit rate and body weight correlations before and after hemodialysis session”, Clinics (Sao Paulo), vol. 64, no. 10, pp. 941-945, 2009. doi: 10.1590/S1807-59322009001000002.

[18] J. E. Trevizoli, R. de Paula Menezes, L. F. Ribeiro Velasco, R. Amorim, M. B. de Carvalho, L. S. Mendes, C. J. Neto, J. R. de Deus Macedo, F. de Assis, R. Neves, "Hepatitis C is less aggressive in hemodialysis patients than in nonuremic patients", Clin. J. Am. Soc. Nephrol., vol. 3, no. 5, pp. 1385-1390, Sep. 2008. doi: 10.2215/CJN.01330308.

[19] L. Ray, S. K. Nanda, A. Chatterjee, R. Sarangi, S. Ganguly, "A comparative study of serum aminotransferases in chronic kidney disease with and without end-stage renal disease: Need for new reference ranges", Int. J. Appl. Basic Med. Res., vol. 5, no. 1, pp. 3135, Jan-Apr. 2015. doi: 10.4103/2229-516X.149232.

[20] F. Fabrizi, G. Lunghi, S. Finazzi, P. Colucci, A. Pagano, C. Ponticelli, F. Locatelli, "Decreased serum aminotransferase activity in patients with chronic renal failure: impact on the detection of viral hepatitis", Am. J. Kidney Dis., vol. 38, no. 5, pp. 1009,1015, Nov. 2001.

[21] J.H.D.A. van Beek, M.H.M. de Moor, E.J.C. de Geus, G.H. Lubke, J.M. Vink, G. Willemsen, D.I. Boomsma, "The Genetic Architecture of Liver Enzyme Levels: GGT, ALT and AST”, Behav Genet, vol. 43, no. 4, pp. 329-339, 2013. doi: 10.1007/s10519013-9593-y.

[22] N. Ul Amin, R. T. Mahmood, M. Javaid Asad, M. Zafar, A. M. Raja, "Evaluating Urea and Creatinine Levels in Chronic Renal Failure Pre and Post Dialysis: A Prospective Study", Journal of Cardiovascular Disease, vol. 2, no. 2, 2014. http://www.researchpub.org/journal/jcvd/jcvd.html.

[23] K. Yokoyama, M. Taniguchi, M. Fukagawa, “A Japanese approach for CKD-MBD”, Kidney international supplements, vol. 3, no. 5, pp. 451-456, 2013. https://doi.org/10.1038/kisup.2013.94.

[24] A. Collinson, M. McMullan, W.Y. Tse, H. Sadler, "Managing serum phosphate in haemodialysis patients: time for an innovative approach?", Eur J Clin Nutr, vol. 68, no. 3, pp. 392-396, 2014. doi:10.1038/ejen.2013.283.

[25] A. Gupta, L. R. Kallenbach, G. Zasuwa, W. Divine, "Race is a major determinant of secondary hyperparathyroidism in uremic patients", J. Am. Soc. Nephrol., vol. 11, no. 2, pp. 330-334, Feb. 2000.

Publish your books with AIJR publisher-

* Publish with ISBN and DOI.

* Publish Thesis/Dissertation as Monograph.

* Publish Book Monograph.

* Publish Edited Volume/ Book.

- Publish Conference Proceedings

- Retain full copyright of your books.

Submit your manuscript at books.aijr.org
Publish your research article in AIJR journals-

* Online Submission and Tracking

* Peer-Reviewed

* Rapid decision

* Immediate Publication after acceptance

* Articles freely available online

- Retain full copyright of your article.

Submit your article at journals.aijr.in 